\title{
Determinan Pertumbuhan Ekonomi Propinsi Sulawesi Selatan
}

\author{
Andi Samsir \\ Program Studi Ekonomi Pembangunan Universitas Negeri Makassar \\ Email: Syamsir_fe03unm@yahoo.co.id
}

\begin{abstract}
ABSTRAK
Keterbatasan modal pada suatu wilayah menjadi kendala tersendiri dalam meningkatkan pertumbuhan ekonomi wilayah tidak terkecuali di Propinsi Sulawesi Selatan. Oleh karena itu, penggunaan anggaran harus mengacu pada skala prioritas program pembangunaan di wilayah tersebut. Penelitian ini ditujukan untuk memperoleh informasi tentang analisis pengaruh pendapatan asli daerah, dana alokasi umum dan dana alokasi khusus terhadap pertumbuhan ekonomi di Sulawesi Selatan. Jenis penelitian ini adalah penelitian ekspalantori dengan menggunakan data time-series yang dikumpulkan melalui teknik studi pustaka. Berdasarkan hasil analisis menunjukan bahwa dana alokasi umum dan alokasi khusus berpengaruh positif terhadap pertumbuhan ekonomi di Sulawesi Selatan. Sementara itu, pendapatan asli daerah tidak berpengaruh terhadap pertumbuhan ekonomi di Sulawesi Selatan.
\end{abstract}

Kata kunci: Pertumbuhan ekonomi, Pendapatan asli daerah, dana alokasi umum, dana akokasi khusus

\begin{abstract}
The capital constraints of region become an obstacle of regional Economy growth including in South Sulawesi Province. Therefore, the use of the budget should be based on program priorities in the regional development. This study aimed to obtain information about the analysis of the influence of region own source revenues, general purpose grant and special purpose grant to economy growth in South Sulawesi. This research is a ekspalantory study using time-series data collected through library research techniques. Based on the results of the analysis showed that the general purpose grant and special purpose grant have positive effect on economic growth in South Sulawesi. Meanwhile, region own source revenues do not affect the economic growth in South Sulawesi.
\end{abstract}

Keywords: Economy growth, region own source revenues, general purpose grant, special purpose grant

\section{PENDAHULUAN}

Sebagai salah satu wilayah fungsional, Sulawesi Selatan juga merupakan pusat kegiatan ekonomi khususnya di Kawasan Timur Indonesia (Bulohlabna, 2008; Danastri \& Hendarto, 2011; Haryono \& Joko, 2005). Struktur perekonomian Sulawesi Selatan masih mencirikan sektor tradisional, sebagaimana tampak pada pertumbuhan ekonomi Sulawesi Selatan selama 
tahun 2006-2014, di atas pertumbuhan nasional dan terus menunjukan pertumbuhan positif (Zain, 2016). Penyumbang terbesar terhadap pertumbuhan tersebut sebagaimana ditunjukan pada Data TNP2K (2015) pada tahun 2013 berasal dari sektor pertanian yaitu sebesar 28,57 persen; sektor perdagangan, hotel dan restoran sebesar 16,47 persen; sektor industri berada pada urutan ketiga sebesar 13,67 persen (Adhitya, 2016).

Keterbatasan modal pada negara-negara berkembang menjadi kendala tersendiri dalam meningkatkan pertumbuhan ekonomi sebagaimana yang dikemukan (Dahuri, 2003; Hafidhuddin, 2002; Rustiadi, Saefulhakim, \& Panuju, 2009; Sarwono \& Warjiyo, 2003). Besarnya pembentukan modal tetap bruto di Sulawesi Selatan pada tahun 20014 hanya sebesar Rp 21,645 triliun atau sekitar 14,99 persen dari PDRB Sulawesi Selatan. Sementara itu, pengeluaran pemerintah sebesar 14,88 persen yang terdiri atas belanja tidak langsung 52,42 peren dan belanja langsung sebesar 37,52 persen (BPS Sulsel, 2014). Oleh karena itu, menurut Hirchman bahwa sebaiknya investasi dilakukan pada beberapa sektor atau sektor yang terpilih saja agar dapat lebih cepat berkembang dan hasilnya digunakan untuk membangun sektor yang lain (Hafidhuddin, 2002; Soetrisno, 2002).

Sebagaimana arah kebijakan pembangunan jangka panjang Sulawesi Selatan 2008-2028 "Menjadikan Wilayah Sulawesi Selatan sebagai satu kesatuan sosial-ekonomi yang berkeadilan" (Bohari, 2009; Tamimi, 2015). Sasaran yang diharapkan dari arah kebijakan tersebut adalah terciptanya pertumbuhan ekonomi yang berkualitas dan berkelanjutan yang dapat mendorong peningkatan pendapatan perkapita dan kesempatan kerja sehingga dapat mengurangi tingkat kemiskinan (RPJPD Sulsel 2008-2028). Untuk mencapai tujuan tersebut pemerintah daerah dalam RPJMD Sulsel 2008-2013 telah merumuskan tahap-tahap pembangunan Sulawesi Selatan dengan tetap menjadikan sektor pertanian sebagai tumpuan pertumbuhan ekonomi daerah. Hal ini dapat dilihat dalam program gerakan optimalisasi jagung, padi dan sapi sebagai program unggulan gubernur Syahrul Yasin Limpo. Program tersebut tidak jauh berbeda dengan program pemerintahan sebelumnya seperti gerakan peningkatan ekspor (Gerateks) pertanian oleh gubernur HZB. Palaguna (1993-2003) dan pengembangan ekonomi masyarakat (Gerbang emas) oleh gubernur Amin Syam (2003-2008).

\section{METODE PENELITIAN}

Jenis data yang digunakan dalam penelitian ini adalah data kuantitatif, dengan jenis data time series (Bachri, 2010). Data kuantitatif terdiri dari Pendapatan Asli Daerah, Dana Alokasi Umum, dan Dana Alokasi Khusus, serta pertumbuhan ekonomi di Sulawesi Selatan. Dalam penelitian ini, terdapat dua variabel yang digunakan yaitu variabel independen (bebas) yaitu Pendapatan Asli Daerah, Dana Alokasi Umum, dan Dana Alokasi Khusus, dan variabel dependen (terikat) yaitu Pertumbuhan Ekonomi. Teknik pengumpulan data yang digunakan pada penelitian ini adalah studi pustaka sebagai metode pengumpulan data (Muhadjir, 2006). Periode data yang akan digunakan dalam penelitian ini adalah tahun 1998-2012. Sementara itu, alat analisis yang digunakan adalah analisis regresi linier berganda yang digunakan untuk melihat pengaruh Pendapatan Asli Daerah, Dana Alokasi Umum, dan Dana Alokasi Khusus terhadap Pertumbuhan Ekonomi. 


\section{HASIL PENELITIAN PEMBAHASAN}

Pengaruh pendapatan asli daerah, dana alokasi umum, dana alokasi khusus terhadap pertumbuhan ekonomi di Sulawesi Selatan menggunakan analisis regresi panel data (panel data) dengan metode fixed effect juga pengujian asumsi klasik. Dimana hasil uji multikolinieritas dengan metode variance inflaction factor (VIF) tidak menunjukan terjadi multikolineritas. Sementara itu, uji B-G test yang digunakan untuk menguji autokorelasi mengindikasikan bahwa dalam penelitian ini juga tidak terjadi autokorelasi. Selanjutnya pengujian ketepatan model atau kesesuaian model (goodness of fit) dari nilai adjusted $\mathrm{R}^{2}$ menunjukan bahwa sumbangan variable independen terhadap variable dependen pada model tersebut sebesar 48,8 persen sementara sisanya sebesar 51,2 persen merupakan sumbangan dari factor lainnya yang tidak termasuk dalam model.

Tabel 1.

Hasil analisis pengaruh Pendapatan Asli Daerah, Dana Alokasi Umum dan Dana Alokasi Khusus terhadap pertumbuhan ekonomi di propinsi Sulawesi Selatan

\begin{tabular}{lccccc}
\hline Variable Independen & T.H & B & $\mathrm{T}_{\text {hitung }}$ & Sig. & VIF \\
\hline Pendapatan asli daerah & + & $-0,011$ & $-0,049$ & 0,961 & 2,966 \\
Dana Alokasi Umum & + & 0,913 & 1,893 & 0,063 & 3,103 \\
Dana Alokasi Khusus & + & 0,702 & 2,317 & 0,024 & 2,477 \\
\hline Intersept & & & & $-23,172$ \\
Adjusted R & & & & 0,488 \\
F $_{\text {hitung }}$ & & & & & 8,754 \\
DW & & & & & 1,315 \\
$\mathrm{~N}$ & & & & & 66 \\
\hline
\end{tabular}

Sumber: hasil pengelolaan data 2016

Nilai intersep pada persamaan tersebut menunjukan bahwa pertumbuhan ekonomi di Sulawesi Selatan akan mengalami pertumbuhan sebesar 6,729 persen meski tanpa adanya variable independen. Selanjutnya uji-F menunjukan bahwa Pendapatan Asli Daerah, Dana Alokasi Umum, dan Dana Alokasi Khusus bersama-sama berpengaruh positif terhadap pertumbuhan ekonomi di Sulawesi Selatan yaitu sebesar 8,754 pada tingkat kesalahan 1 persen. Sementara itu, uji parsial dengan menggunakan uji-t menunjukan bahwa pendapatan asli daerah tidak berpengaruh terhadap pertumbuhan ekonomi Sulawesi Selatan sedangkan dua variable lainnya yaitu dana alokasi umum dan dana alokasi khusus berpengaruh positif. Berdasarkan analisis yang telah digunakan, maka diperoleh persamaan berikut:

$$
\mathrm{PE}_{\mathrm{it}}=-23,172-0,011 \mathrm{LnPAD}_{\mathrm{it}}+0,913 \mathrm{Ln} \mathrm{DAU}_{\mathrm{it}}+0,702 \mathrm{Ln} \mathrm{DAK}+\mu
$$


Dari persamaan 3 maka persamaan tersebut diubah kembali ke bentuk awal (persamaan 1) dengan meng-anti LN kan sebagai berikut:

$$
\mathrm{PE}_{\mathrm{it}}=6,729 \mathrm{PAD}_{\mathrm{it}}{ }^{-0,011} \cdot \mathrm{DAU}_{\mathrm{it}}^{0,913} \cdot \mathrm{DAK}_{\mathrm{it}}^{0,702}+\mu
$$

Berdasarkan hasil penelitian dengan analisis secara statistik menunjukan bahwa Dana Alokasi Umum berpengaruh positif terhadap pertumbuhan di Sulawesi Selatan yaitu sebesar 0,913 dengan tingkat singnifikansi 0,063 . Hal ini berarti bahwa setiap penambahan Dana Alokasi Umum sebesar 1 persen yang diterima oleh pemerintah Sulawesi Selatan akan meningkatkan pertumbuhan ekonomi di Sulawesi Selatan sebesar 0,913 persen. Sementara itu, hasil analisis secara empiris menunjukan bahwa kenaikan Dana Alokasi Umum sebesar 289,4 miliar dapat mendorong pertumbuhan ekonomi sebesar 7,34 persen.

Hal yang sama juga ditunjukan oleh Dana Alokasi Khusus yang mana berpengaruh positif yaitu sebesar 0,702 terhadap pertumbuhan ekonomi di Sulawesi Selatan dengan tingkat signifikansi sebesar 0,024. Hal ini berarti bahwa setiap penambahan Dana Alokasi Khusus yang diterima oleh pemerintah Sulawesi Selatan akan meningkatkan pertumbuhan ekonomi di Sulawesi Selatan sebesar 0,024 persen. Secara empiris, setiap kenaikan Dana Alokasi Umum sebesar 32,2 miliar rupiah akan meningkatkan pertumbuhan ekonomi di Sulawesi selatan sebesar 7,34 persen.

Besarnya nilai adjusted $\mathrm{R}^{2}$ memberikan gambaran besarnya kontribusi kedua variable yang diukur, yaitu dana alokasi umum dan alokasi khusus terhadap pertumbuhan ekonomi di Sulawesi Selatan. Berdasarkan teori Nurkse melalui kedua variable tersebut yang merupakan aspek penerimaan pemerintah dapat digunakan untuk memberikan intervensi yang sama terhadap semua sector ekonomi untuk menciptakan pertumbuhan ekonomi. Sementara itu, menurut Hirschman keterbatasan anggaran (budget constraint) yang di miliki sebaiknya pemerintah memberikan intervensi pada sector yang dianggap sebagai sector utama (leading sector). Penggunaan dana alokasi umum dan dana alokasi khusus dalam membiayai kegiatan ekonomi di daerah masih merujuk pada undang undang nomor 33 tahun 2004 dan peraturan pemerintah nomor 55 tahun 2005 tentang dana perimbangan.

Penggunaan dana alokasi umum (general purpose grant) di Sulawesi Selatan untuk membiayai kegiatan ekonomi di berbagai sector lebih fleksibel dibandingkan dana alokasi khusus (specific purpose grant). Bantuan yang bersifat umum atau bantuan tanpa syarat merupakan jenis yang bebas digunakan oleh si penerima dan tidak ada arahan terhadap penggunaan dana tersebut dan tujuannya ditujukan untuk pemerataan kemampuan fiscal antar daerah. Sementara itu, bantuan yang bersifat khusus ditujukan untuk membiayai bidang tertentu yang telah menjadi kewenangan daerah otonomi, namun pemerintah daerah sebagai penerima tidak dapat menggunakan dana tersebut kecuali untuk kegiatan yang telah ditentukan oleh pemerintah pusat.

Dengan adanya kebijakan desentralisasi fikal tersebut, lebih memudahkan pemerintah daerah khususnya Sulawesi Selatan mengatur pengalokasian penggunaan anggaran untuk membiayai program yang menjadi prioritas daerah. Sesuai dengan hasil analisis yang menunjukan besarnya pengaruh dana alokasi umum dibandingkan dana alokasi khusus mempengaruhi pertumbuhan ekonomi di Sulawesi Selatan tidak terlepas dari adanya kebijakan 
penggunaan anggaran tersebut. Meskipun demikian, besarnya anggaran penerimaan dari variable tersebut masih bergantung pada komponen jumlah penduduk, luas wilayah, luas perairan, indeks kemahalan, PDRB perkapita dan indeks pembangunan manusia. Oleh karena itu, pemerintah daerah tidak dapat berbuat banyak dalam memaksimalkan besaran penerimaan tersebut selain mengatur penggunaan anggaran sesuai dengan teori Hirchman.

\section{SIMPULAN}

Berdasarkan hasil analisis data penelitian dapat ditarik kesimpulan bahwa Dana Alokasi Umum dan Alokasi Khusus berpengaruh positif terhadap pertumbuhan ekonomi di Sulawesi Selatan. Sementara itu, pendapatan Asli Daerah tidak berpengaruh terhadap pertumbuhan ekonomi di Sulawesi Selatan.

\section{DAFTAR PUSTAKA}

Adhitya, R. (2016). Analisis Kebijakan Alokasi Investasi dalam rangka mengatasi masalah Kemiskinan di Provinsi Papua.

Bachri, B. S. (2010). Meyakinkan validitas data melalui triangulasi pada penelitian kualitatif. Jurnal Teknologi Pendidikan, 10(1), 46-62.

Bohari, R. (2009). Model kebijakan pengelolaan wilayah pesisir secara terpadu dan berkelanjutan di perairan pantai Makassar Sulawesi Selatan.

Bulohlabna, C. (2008). Tipologi dan Pengaruh Infrastruktur terhadap Pertumbuhan Ekonomi Kawasan Timur Indonesia.

Dahuri, R. (2003). Paradigma baru pembangunan Indonesia berbasis kelautan.

Danastri, S., \& Hendarto, R. M. (2011). Analisis Penetapan Pusat-Pusat Pertumbuhan Baru di Kecamatan Harjamukti, Cirebon Selatan. Universitas Diponegoro.

Hafidhuddin, D. (2002). Zakat dalam perekonomian modern. Gema Insani.

Haryono, T. J. S., \& Joko, T. (2005). Strategi Kelangsungan Hidup Nelayan: Studi tentang diversifikasi pekerjaan keluarga nelayan sebagai salah satu strategi dalam mempertahankan kelangsungan hidup. Berkala Ilmiah Kependudukan, 7(2), 126-127.

Muhadjir, N. (2006). Metode Penelitian. Cetakan kedua, Alfabeta, Bandung.

Rustiadi, E., Saefulhakim, S., \& Panuju, D. R. (2009). Perencanaan dan pengembangan wilayah. Yayasan Pustaka Obor Indonesia.

Sarwono, H. A., \& Warjiyo, P. (2003). Mencari Paradigma Baru Manajemen Moneter Dalam SIstem Nilai Tukar Fleksibel: Suaru Pemikiran untuk Penerapannya di Indonesia. Bulletin of Monetary Economics and Banking (Buletin Ekonomi Moneter Dan Perbankan), 1(1), 523.

Soetrisno, L. (2002). Paradigma baru pembangunan pertanian: sebuah tinjauan sosiologis. Kanisius.

Tamimi, Z. (2015). Inovasi Manajemen Pelayanan Publik Tim Emergency Service Kabupaten Bantaeng. POLITIKA: Jurnal Ilmu Politik, 6(1), 141-158.

Zain, M. M. (2016). Elastisitas Permintaan Tenaga Kerja dan Kekakuan Upah Riil Sektoral di Sulawesi Selatan. Jurnal Agro Ekonomi, 28(2), 113-132. 